\title{
Dental Press Journal of Orthodontics
}

\section{Correlation between cortical bone thickness at mini-implant insertion sites and age of patient}

\author{
Anna Carolina Teixeira CENTENO 1 \\ (i) https://orcid.org/0000-0002-1356-0256 \\ Caroline Kolling FENSTERSEIFER ${ }^{1}$ \\ (i) https://orcid.org/0000-0002-0618-5304 \\ Vitória de Oliveira CHAMI ${ }^{1}$ \\ (i) https://orcid.org/0000-0002-1850-2530 \\ Eduardo Silveira FERREIRA² \\ (iD https://orcid.org/0000-0002-4925-2079 \\ Mariana MARQUEZAN ${ }^{1}$ \\ (i) https://orcid.org/0000-0001-6078-5194 \\ Vilmar Antônio FERRAZZO' $₫$ \\ (i) https://orcid.org/0000-0002-2792-9034
}

Submitted: June 05, 2020 Revised and accepted: September 24, 2020 凶vilmarferrazzo@gmail.com

(1) Universidade Federal de Santa Maria, Curso de Odontologia, Departamento de Estomatologia (Santa Maria/RS, Brazil). (2) Universidade Federal do Rio Grande do Sul, Faculdade de Odontologia, Departamento de Ortodontia (Porto Alegre/RS, Brazil). 


\section{ABSTRACT}

Introduction: Orthodontic mini-implants (MI) are a reliable alternative to provide temporary orthodontic anchorage. Prior to miniscrew insertion, the best approach would be to evaluate each possible insertion site and measure the cortical bone thickness, and verify whether it would provide adequate primary stability. Objective: This study aimed to evaluate the difference in cortical bone thickness in areas of mini-implants insertion in patients of different ages, by means of cone beam computed tomography (CBCT). Methods: The sample of this retrospective study was composed of 123 CBCT scans, which were used to measure cortical bone thickness in the buccal and palatal inter-radicular space in the mesial region of the first permanent molars. These measures were compared by using the Student's t-test, ANOVA/Tukey tests, and Linear regression between male and female subjects, from 12 to 30 years old. Results: No significant difference was found in cortical bone thickness between sex, race and sagittal facial patterns. Significantly higher measurement values were observed in patients older than 12 years of age at all sites evaluated. The coefficient $\beta$ at the adjusted linear regression analysis showed that at each increment in age, mean cortical thickness values increased by $0.06 \mathrm{~mm}$ in the mandible, $0.03 \mathrm{~mm}$ in the buccal region and $0.02 \mathrm{~mm}$ in the palatal region of the maxilla. Conclusions: The increase in cortical bone thickness was positively associated with age; that is, the more advanced the patient's age was, the less chance there was of failure due to primary stability.

Keywords: GBCT. Orthodontic mini-implant. Stability. 


\section{RESUMO}

Introdução: Os mini-implantes ortodônticos (MI) são uma alternativa confiável para fornecer ancoragem esquelética temporária. Antes da inserção do mini-implante, a melhor abordagem seria avaliar cada local de inserção possível, medir a espessura do osso cortical e verificar se proporcionaria uma adequada estabilidade primária. Objetivo: O presente estudo teve como objetivo avaliar a diferença na espessura do osso cortical em áreas de inserção dos mini-implantes em pacientes de diferentes idades, por meio da tomografia computadorizada de feixe cônico. Métodos: A amostra desse estudo retrospectivo foi composta por 123 tomografias computadorizadas de feixe cônico, que foram utilizadas para medir a espessura do osso cortical nos espaços inter-radiculares vestibular e palatino na região mesial dos primeiros molares permanentes. Essas medidas foram comparadas por meio dos testes $t$ de Student, ANOVA/Tukey e regressão linear entre os sexos masculino e feminino, de 12 a 30 anos. Resultados: Não houve diferença estatisticamente significativa na espessura cortical, quando comparados sexo, cor da pele e padrão facial sagital. Foram verificadas medidas significativamente maiores em pacientes com idade superior a 12 anos em todos os sítios avaliados. $O$ coeficiente $\beta$ da análise de regressão linear ajustada mostrou que, a cada incremento da idade, os valores médios da espessura cortical aumentaram 0,06 $\mathrm{mm}$ na mandíbula, 0,03 $\mathrm{mm}$ na região vestibular e 0,02 $\mathrm{mm}$ na região palatina da maxila. Conclusão: O aumento da espessura do osso cortical teve associação positiva com a idade, ou seja, quanto mais avançada a idade do paciente, menor a chance de falha, devido à estabilidade primária.

Palavras-chave: Tomografia computadorizada de feixe cônico. Mini-implante ortodôntico. Estabilidade. 


\section{INTRODUCTION}

Orthodontic mini-implants (MI) are a reliable alternative to provide temporary orthodontic anchorage. ${ }^{1}$ Approximately $80 \%$ of orthodontists use miniscrews, and according to approximately $78 \%$ of professionals, they provide better results in orthodontic treatments. ${ }^{2}$ Nevertheless, failure rates range from $11 \%$ to $30 \%$. $^{3}$ To stratify the risks of the procedure for inserting anchorage screws, it is necessary to know which site has the thickest cortical bone, at "different ages, for the purpose of guaranteeing the primary stability of the mini-implant and making the outcome of the orthodontic treatment more predictable.

Primary stability of the miniscrews basically depends on the screw design, insertion technique, and quality and quantity of bone at the insertion site. ${ }^{4-7}$ Among these factors, the cortical bone thickness of the insertion site is emphasized. ${ }^{8,9}$

Prior to miniscrew insertion, the best approach would be to evaluate each possible insertion site by means of cone beam computed tomography (CBCT), to measure the cortical bone thickness, and to verify whether it would provide adequate primary stability. However, using this exam for this purpose is not indicated, according to the American Academy of Oral and Maxillofacial Radiology (AAOMR). ${ }^{10}$

Thus, the aim of this study was to evaluate the cortical bone thickness at different mini-implant insertion sites in the maxilla 
and mandible, and correlate this with the age of the patient, since the choice of the best site and age has direct repercussion on the reduction of cost and treatment time.

Other variables related to the individuals, such as age, sex, skin color, vertical and sagittal facial patterns would be analyzed through a multivariate analysis, to verify its interaction on the main outcome (age). The hypothesis of the present study was that patients with a more advanced age would present a greater cortical bone thickness, and consequently mini-implants would present a higher degree of primary stability.

\section{MATERIAL AND METHODS}

To conduct this retrospective study, the clinical record charts of patients of the Orthodontic Specialization Course, treated at the Dental School of the Federal University of Rio Grande do Sul (Brazil), were reviewed with regard to the orthodontic documentation of patients that met the following inclusion criteria: (1) initial phase orthodontic patients; (2) mixed or permanent dentition; (3) orthodontic documentation containing data of CBCT performed at the same private radiology center (CBCT scanned in i-CAT ${ }^{\circledR}$, field of view $22 \times 16 \mathrm{~cm}$, isotropic voxel of $0.4 \mathrm{~mm}$, images acquired with a rotation of $360^{\circ}$ during 20s, $120 \mathrm{kVp}, 36.90 \mathrm{mAs}$, and data saved in DICOM format). Patients with pathologies or radiolucency in the areas of measurement; periodontal disease; ectopic eruptions at sites of interest and important medical history were excluded. 
The research protocol was submitted to and approved by the Ethics Committee of Federal University of Rio Grande do Sul (CAAE 83140118.4.0000.5347). The database search was performed between July 2017 and April 2018, and 800 orthodontic charts were reviewed. Of these, 123 were selected according to a sample calculation performed with data obtained from a pilot study using 57 individuals from the same database (study power of $80 \%$, significance level of $0.05 \%$, and correlation coefficient of 0.25 ).

Data regarding age, sex and skin color were collected from the clinical records of the selected patients. In addition, the CBCT images were imported into Dolphin Imaging Cephalometric and Tracing software, version 11.8 (Dolphin Imaging and Management Solutions, Chatsworth, Calif., USA), for the purpose of measuring the cortical bone thickness of the selected sites and assessing the sagittal and the vertical facial patterns. Subjects were categorized according to their facial patterns (sagittal and vertical) using lateral cephalograms (right side) synthesized from the CBCT. For this purpose, the tomographic volume was oriented with the perpendicular sagittal mean plane and the Frankfurt plane (right side of the face) parallel to the ground. Subsequently, the cephalometric analyses of Steiner ${ }^{11}$ and Ricketts ${ }^{12}$ were performed. For classification of the sagittal facial pattern, angle ANB of the Steiner analysis was used: Class I $\left(0^{\circ}<\mathrm{ANB}<4.5^{\circ}\right)$, Class II $\left(\mathrm{ANB} \geq 4.5^{\circ}\right)$, Class III $\left(\mathrm{ANB} \leq 0^{\circ}\right)$. 
The vertical facial pattern was determined by means of the Ricketts VERT index, which classifies individuals into dolichocephalic (VERT < -0.50); mesocephalic $(-0.49<$ VERT $<0.49)$, and brachycephalic (VERT > 0.50) facial types.

The cortical bone thickness was measured in cross-sections, generated after determining the arc curvature line (Fig 1). The sites evaluated for cortical bone thickness were: inter-radicular space located in the mesial region of the maxillary and mandibular permanent first molars, where the maxilla was evaluated in the vestibular and palatine regions and the mandible, only in the vestibular region, since these are considered safe sites for mini-implant insertion. ${ }^{13}$ The lingual cortical mandibular bone thickness was not measured, because it is not an area commonly used for miniscrew placement.

Measurements were performed at a distance of $5 \mathrm{~mm}$ from the alveolar bone crest (Fig 2), because there is usually an adequate amount of bone in this position for inserting miniscrews; ${ }^{14,15}$ moreover, there is inserted gingiva that favors successful insertion of the device. ${ }^{16}$ For each patient, six measurements (right and left side) were obtained with the millimeter ruler provided by the software. For statistical analysis, the measurements were grouped into three units of evaluation: vestibular maxilla (measurements made on the vestibular cortical bone 


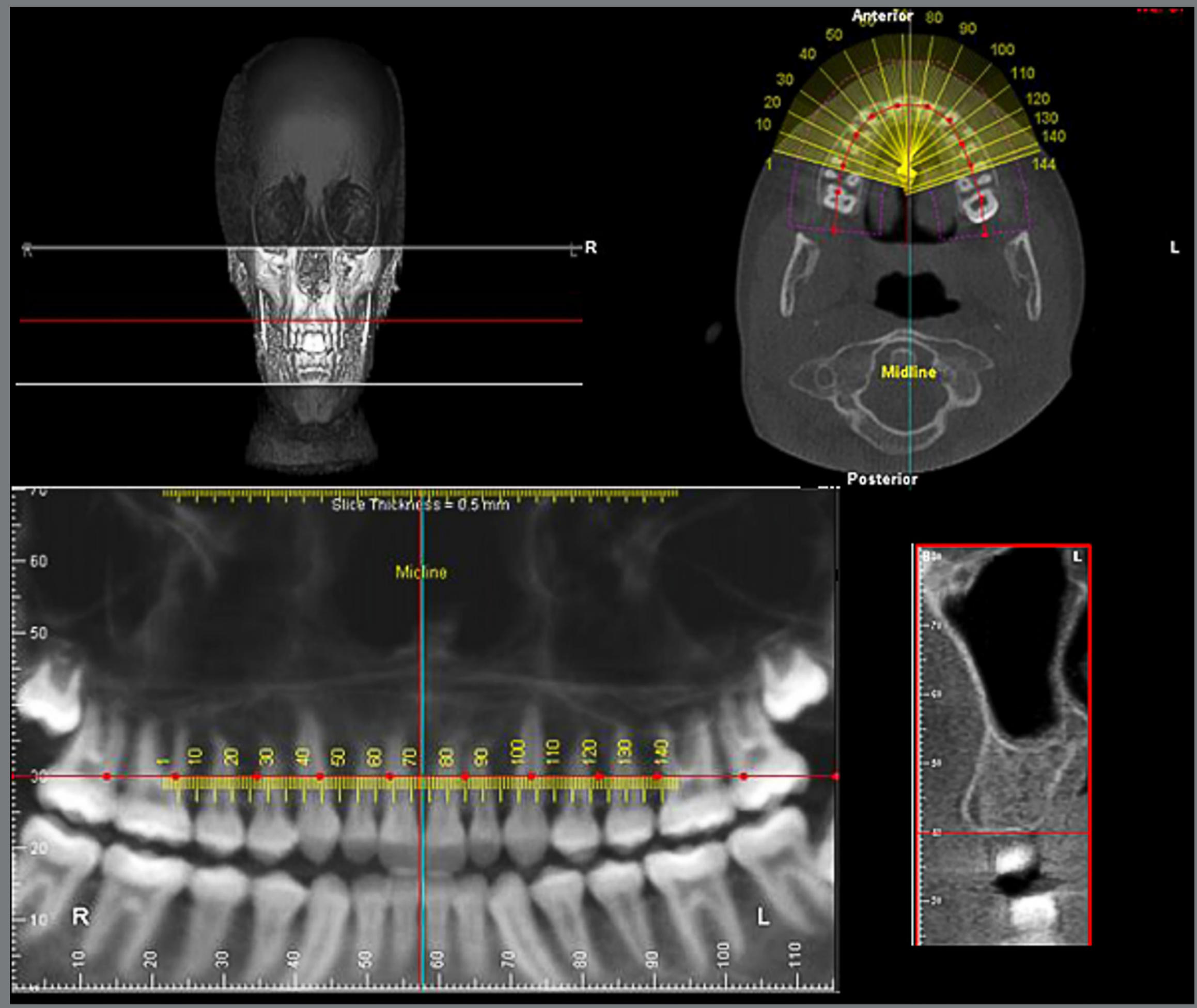

Figure 1: Determination of cross sections. 


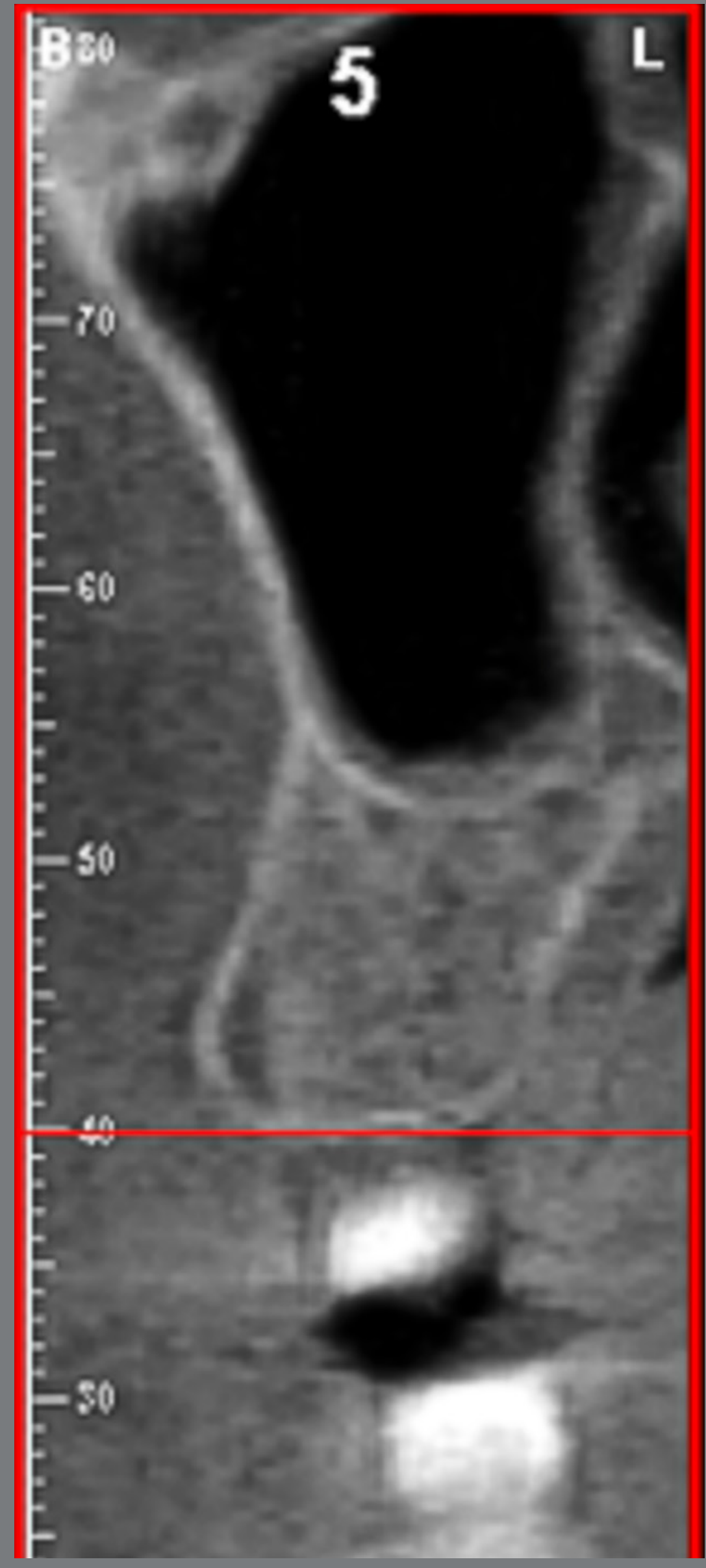

Figure 2: Measurement of vestibular and lingual cortical bone thickness at the determined heights $(5 \mathrm{~mm}$ from the bone crest). of the maxilla on both sides); palatal maxilla (measurements made on the palatal bone cortex of the maxilla on both sides); Mandible (measurements made on the vestibular cortical of the mandible on both sides). To minimize possible biases in the survey, each subject was given a registration number, which was obtained by lot, to determine the sequence of the images to be analyzed. A trained and calibrated examiner performed measurements. Twenty-five individuals $(20 \%$ of the sample) were initially evaluated and reassessed after three weeks to verify reproducibility. The Kappa index was used for categorical variables (ANB and VERT index), and the intraclass correlation coefficient (ICC), for quantitative variables (cortical bone thickness). Excellent reproducibility (Kappa> 0.80 / ICC> 0.75) was found for all measures analyzed. 
Statistical analysis was performed in STATA 14.0 software (Stata Corporation, CollegeStation, TX, USA). After a descriptive analysis and normality tests, the Student's $t$-test was performed to compare means between individuals of the male and female sexes in the age range of 12 years or older, and white and non-white individuals. ANOVA/Tukey tests were performed to compare brachy-, meso- and dolichofacial individuals, and to compare Class I, II and III. Subsequently, unadjusted linear regression analysis was performed to verify the relationship between individual characteristics and cortical bone measurements. After the unadjusted analysis, the variables with $p$-value $<0.20$ were included in the adjusted regression analysis. In addition, the sex variable was also included as an adjustment variable. A 95\% confidence interval and $p$-value $<0.05$ represented a statistically significant relationship.

\section{RESULTS}

The median age of the 123 patients selected was 12.1 years (7.6 - 30.7). Table 1 shows the sample frequencies and distribution by sex, age, skin color, vertical facial pattern (VERT) and sagittal facial pattern (ANB). 
Table 1: Descriptive distribution of sex, age, skin color and facial patterns of the sample.

\begin{tabular}{c|c}
\hline Sex & $n(\%)$ \\
\hline Male & $53(43.09)$ \\
\hline Female & $70(56.91)$ \\
\hline Age & $64(52.03)$ \\
\hline$<12$ years & $59(47.97)$ \\
\hline Skin color & \\
\hline White & $107(86.99)$ \\
\hline Non-white & $16(13.01)$ \\
\hline VERT & $28(22.76)$ \\
\hline Dolichofacial & $42(34.15)$ \\
\hline Mesofacial & $53(43.09)$ \\
\hline Brachyfacial & \\
\hline ANB & $43(34.96)$ \\
\hline Class I & $61(49.59)$ \\
\hline Class II & $19(15.45)$ \\
\hline Class III & \\
\hline
\end{tabular}

Unadjusted and adjusted linear regression analysis for sex, skin color, age, vertical facial (VERT) and sagittal (ANB) facial pattern was performed to simultaneously evaluate the effect of multiple individual patient factors on the cortical bone thickness (Table 2). The results of adjusted linear regression analysis showed that sex, skin color and sagittal facial pattern had no significant effect on bone thickness. However, the increase in age significantly influenced the increase in cortical bone thickness in all evaluated areas. The coefficient $\beta$ showed that with each increase in age, the mean cortical thickness values increased by $0.06 \mathrm{~mm}$ in the mandible, $0.03 \mathrm{~mm}$ in the vestibular region of the maxilla and $0.02 \mathrm{~mm}$ in the palatal region of the maxilla. The direction of facial growth was shown to influence the thickness of the mandibular vestibular cortical bone $(p<0.00)$. 
Table 2: Comparison between individual characteristics and bone measurements (Student $t$-test and ANOVA/Tukey).

\begin{tabular}{|c|c|c|c|c|c|c|}
\hline & $\begin{array}{l}\text { Mandible } \\
\text { Mean (SD) }\end{array}$ & $p$-value & $\begin{array}{l}\text { Vestibular } \\
\text { Maxilla } \\
\text { Mean (SD) } \\
\end{array}$ & $p$-value & $\begin{array}{c}\text { Palatal } \\
\text { Maxilla } \\
\text { Mean (SD) }\end{array}$ & $p$-value \\
\hline Sex & & 0.82 & & 0.17 & & 0.23 \\
\hline Male & $2.65(0.64)$ & & $1.94(0.36)$ & & $2.05(0.34)$ & \\
\hline Female & $2.62(0.60)$ & & $2.03(0.32)$ & & $2.12(0.33)$ & \\
\hline Age & & $<0.00$ & & $<0.00$ & & $<0.00$ \\
\hline$<12$ years & $2.44(0.51)$ & & $1.87(0.27)$ & & $1.98(0.30)$ & \\
\hline$>12$ years & $2.84(0.65)$ & & $2.12(0.36)$ & & $2.20(0.34)$ & \\
\hline Skin color & & 0.70 & & 0.39 & & 0.22 \\
\hline White & $2.63(0.63)$ & & $1.98(0.35)$ & & $2.08(0.35)$ & \\
\hline Non-white & $2.68(0.50)$ & & $2.05(0.26)$ & & $2.16(0.23)$ & \\
\hline VERT & & $0.02 *$ & & 0.38 & & 0.47 \\
\hline Dolichofacial & $2.41(0.48)^{a}$ & & $1.96(0.35)$ & & $2.02(0.36)$ & \\
\hline Mesofacial & $2.59(0.59)^{a, b}$ & & $1.95(0.35)$ & & $2.09(0.32)$ & \\
\hline Brachyfacial & $2.79(0.67)^{b}$ & & $2.04(0.33)$ & & $2.12(0.34)$ & \\
\hline ANB & & 0.20 & & 0.22 & & 0.15 \\
\hline Class I & $2.76(0.74)$ & & $2.06(0.33)$ & & $2.15(0.32)$ & \\
\hline Class II & $2.55(0.55)$ & & $1.94(0.33)$ & & $2.02(0.31)$ & \\
\hline Class III & $2.61(0.45)$ & & $2.04(0.35)$ & & $2.15(0.38)$ & \\
\hline
\end{tabular}

* Statistically significant difference.

Different letters represent statistically significant differences between groups $(p<0.05)$.

Significantly higher mean cortical bone thickness values were observed in patients over 12 years of age in all the evaluated sites. As regards the vertical facial pattern, brachycephalic patients had the highest mean cortical bone thickness values in all evaluated areas, but significant differences were observed only in the mandibular vestibular cortical bone (Table 3). More information about the patients of the sample (gender, race and age) can be found at the appendix $A$. 
Table 3: Unadjusted and adjusted linear regression analysis between the individual characteristics and the cortical bone measurements.

\begin{tabular}{|c|c|c|c|c|}
\hline & \multicolumn{2}{|c|}{$\begin{array}{c}\text { Mandible } \\
\text { Unadjusted regression }\end{array}$} & \multicolumn{2}{|c|}{$\begin{array}{c}\text { Mandible } \\
\text { Adjusted regression }\end{array}$} \\
\hline & $\begin{array}{l}\beta \text { coefficient } \\
(\mathrm{Cl}-95 \%)\end{array}$ & $p$-value & $\begin{array}{l}\beta \text { coefficient } \\
(\text { Cl- } 95 \%)\end{array}$ & $p$-value \\
\hline Sex & & 0.82 & & \\
\hline Male & 1 & & - & \\
\hline Female & $-0.03(-0.25-0.20)$ & & - & \\
\hline Skin color & & 0.74 & & \\
\hline White & 1 & & - & \\
\hline Non-white & $0.05(-0.27-0.38)$ & & - & \\
\hline Age & $0.06(0.04-0.09)$ & $<0.00$ & $0.06(0.04-0.08)$ & $<0.00$ \\
\hline VERT & $0.18(0.07-0.29)$ & $<0.00$ & $0.15(0.06-0.25)$ & $<0.00$ \\
\hline \multirow[t]{3}{*}{ ANB } & $0.02(-0.19-0.06)$ & 0.29 & - & \\
\hline & \multicolumn{2}{|c|}{$\begin{array}{l}\text { Vestibular Maxilla } \\
\text { Unadjusted regression }\end{array}$} & \multicolumn{2}{|c|}{$\begin{array}{l}\text { Vestibular Maxilla } \\
\text { Adjusted regression }\end{array}$} \\
\hline & $\begin{array}{l}\beta \text { coefficient } \\
\text { (Cl-95\%) }\end{array}$ & $p$-value & $\begin{array}{c}\beta \text { coefficient } \\
(\mathrm{Cl}-95 \%)\end{array}$ & $p$-value \\
\hline Sex & & 0.16 & & 0.30 \\
\hline Male & 1 & & 1 & \\
\hline Female & $0.09(-0.03-0.20)$ & & $0.06(-0.05-0.17)$ & \\
\hline \multicolumn{5}{|l|}{ Skin color } \\
\hline White & 1 & 0.48 & - & \\
\hline Non-white & $0.06(-0.11-0.24)$ & & - & \\
\hline Age & $0.03(0.02-0.04)$ & $<0.00$ & $0.03(0.01-0.04)$ & $<0.00$ \\
\hline VERT & $0.06(-0.00-0.12)$ & 0.07 & $0.03(-0.02-0.09)$ & 0.23 \\
\hline \multirow[t]{3}{*}{ ANB } & $-0.00(-.02-0.02)$ & 0.98 & - & \\
\hline & \multicolumn{2}{|c|}{$\begin{array}{c}\text { Palatal Maxilla } \\
\text { Unadjusted regression }\end{array}$} & \multicolumn{2}{|c|}{$\begin{array}{c}\text { Palatal Maxilla } \\
\text { Adjusted regression }\end{array}$} \\
\hline & $\begin{array}{c}\beta \text { coefficient } \\
(\mathrm{Cl}-95 \%)\end{array}$ & $p$-value & $\begin{array}{c}\beta \text { coefficient } \\
(\mathrm{Cl}-95 \%)\end{array}$ & $p$-value \\
\hline Sex & & 0.23 & & \\
\hline Male & 1 & & - & \\
\hline Female & $0.07(-0.05-0.19)$ & & - & \\
\hline Skin color & & 0.36 & & \\
\hline White & 1 & & - & \\
\hline Non-white & $0.08(-0.09-0.26)$ & & - & \\
\hline Age & $0.02(0.01-0.03)$ & $<0.00$ & $0.02(0.01-0.03)$ & $<0.00$ \\
\hline VERT & $0.03(-0.03-0.09)$ & 0.35 & - & \\
\hline ANB & $0.01(-0.01-0.03)$ & 0.42 & - & \\
\hline
\end{tabular}


Appendix A: All patients gender, race and age.

\begin{tabular}{|c|c|c|c|}
\hline Patient & Gender & Race & Age \\
\hline 1 & $\mathrm{~F}$ & W & $12 y 5 m$ \\
\hline 2 & $\mathrm{~F}$ & W & $12 \mathrm{y} 10 \mathrm{~m}$ \\
\hline 3 & $\mathrm{~F}$ & W & $30 y$ \\
\hline 4 & $\mathrm{~F}$ & W & $13 y 8 m$ \\
\hline 5 & $M$ & W & $27 y 10 m$ \\
\hline 6 & $\mathrm{~F}$ & W & $12 y 3 m$ \\
\hline 7 & $\mathrm{~F}$ & W & $12 y 8 m$ \\
\hline 8 & $M$ & W & 14 y $1 \mathrm{~m}$ \\
\hline 9 & M & W & 13y 8m \\
\hline 10 & M & W & $17 y$ \\
\hline 11 & $\mathrm{~F}$ & W & $17 y 3 m$ \\
\hline 12 & $\mathrm{~F}$ & W & $18 \mathrm{y} 9 \mathrm{~m}$ \\
\hline 13 & $\mathrm{~F}$ & W & $18 \mathrm{y} 10 \mathrm{~m}$ \\
\hline 14 & $\mathrm{~F}$ & W & $16 y 4 m$ \\
\hline 15 & $M$ & W & $15 y$ 6m \\
\hline 16 & $\mathrm{~F}$ & NW & $12 \mathrm{y} 10 \mathrm{~m}$ \\
\hline 17 & $\mathrm{~F}$ & W & $16 y 10 \mathrm{~m}$ \\
\hline 18 & $\mathrm{~F}$ & W & $11 y 7 m$ \\
\hline 19 & $\mathrm{~F}$ & W & $14 y 5 m$ \\
\hline 20 & $\mathrm{~F}$ & W & 11 y $7 m$ \\
\hline 21 & $\mathrm{~F}$ & NW & $26 y 5 m$ \\
\hline 22 & M & W & $12 \mathrm{y} 10 \mathrm{~m}$ \\
\hline 23 & $F$ & W & $30 y 7 m$ \\
\hline 24 & $M$ & W & $13 y 6 m$ \\
\hline 25 & $\mathrm{~F}$ & W & $12 y 7 m$ \\
\hline 26 & $M$ & W & $13 y 7 m$ \\
\hline 27 & $\mathrm{M}$ & W & $15 y 3 m$ \\
\hline 28 & $M$ & W & $13 y 5 m$ \\
\hline 29 & $M$ & W & $13 \mathrm{y} 2 \mathrm{~m}$ \\
\hline 30 & M & W & $13 y 6 m$ \\
\hline 31 & M & W & $15 y 3 m$ \\
\hline 32 & $\mathrm{~F}$ & NW & $16 y 7 m$ \\
\hline 33 & $M$ & NW & $13 y 10 \mathrm{~m}$ \\
\hline 34 & $\mathrm{~F}$ & W & $13 y 5 m$ \\
\hline 35 & $\mathrm{M}$ & W & $14 y 9 m$ \\
\hline 36 & $M$ & W & $12 \mathrm{y} 11 \mathrm{~m}$ \\
\hline 37 & $\mathrm{~F}$ & W & $15 \mathrm{y} 6 \mathrm{~m}$ \\
\hline
\end{tabular}

\begin{tabular}{|c|c|c|c|}
\hline Patient & Gender & Race & Age \\
\hline 38 & $\mathrm{~F}$ & NW & 11 y $2 \mathrm{~m}$ \\
\hline 39 & $M$ & NW & $16 y 3 m$ \\
\hline 40 & $F$ & NW & $21 y$ \\
\hline 41 & $\mathrm{~F}$ & W & $14 y 5 m$ \\
\hline 42 & $\mathrm{~F}$ & W & $11 \mathrm{y} 2 \mathrm{~m}$ \\
\hline 43 & $\mathrm{~F}$ & W & $12 \mathrm{y} 11 \mathrm{~m}$ \\
\hline 44 & $M$ & NW & $22 \mathrm{y} 10 \mathrm{~m}$ \\
\hline 45 & M & W & $16 y$ \\
\hline 46 & M & W & $12 \mathrm{y} 4 \mathrm{~m}$ \\
\hline 47 & $\mathrm{~F}$ & W & $17 y 2 m$ \\
\hline 48 & $\mathrm{~F}$ & W & $26 y 4 m$ \\
\hline 49 & $\mathrm{~F}$ & W & $14 y 3 m$ \\
\hline 50 & $\mathrm{~F}$ & W & $12 \mathrm{y} 8 \mathrm{~m}$ \\
\hline 51 & $\mathrm{~F}$ & W & $12 \mathrm{y} 11 \mathrm{~m}$ \\
\hline 52 & $M$ & W & $13 y 1 m$ \\
\hline 53 & $\mathrm{~F}$ & W & $16 \mathrm{y} 6 \mathrm{~m}$ \\
\hline 54 & $\mathrm{~F}$ & NW & $12 y 2 m$ \\
\hline 55 & $\mathrm{~F}$ & NW & $12 \mathrm{y} 6 \mathrm{~m}$ \\
\hline 56 & $M$ & W & $25 y 8 m$ \\
\hline 57 & $M$ & W & $14 y 2 m$ \\
\hline 58 & $\mathrm{M}$ & W & $16 y 4 m$ \\
\hline 59 & $\mathrm{~F}$ & W & $23 y 6 m$ \\
\hline 60 & $\mathrm{~F}$ & W & $26 y 4 m$ \\
\hline 61 & $M$ & NW & $11 \mathrm{y} 4 \mathrm{~m}$ \\
\hline 62 & $M$ & W & $19 \mathrm{y} 10 \mathrm{~m}$ \\
\hline 63 & $\mathrm{~F}$ & W & $11 \mathrm{y} 11 \mathrm{~m}$ \\
\hline 64 & $\mathrm{~F}$ & W & $13 y 7 m$ \\
\hline 65 & $M$ & W & $11 y$ \\
\hline 66 & $\mathrm{~F}$ & W & $12 \mathrm{y} 11 \mathrm{~m}$ \\
\hline 67 & $M$ & W & $12 \mathrm{y} 1 \mathrm{~m}$ \\
\hline 68 & $M$ & NW & $17 y 2 m$ \\
\hline 69 & $\mathrm{~F}$ & W & $10 \mathrm{y} 10 \mathrm{~m}$ \\
\hline 70 & $\mathrm{M}$ & W & $12 y 7 m$ \\
\hline 71 & $\mathrm{~F}$ & W & $12 \mathrm{y} 5 \mathrm{~m}$ \\
\hline 72 & $\mathrm{~F}$ & W & $11 \mathrm{y} 8 \mathrm{~m}$ \\
\hline 73 & $\mathrm{~F}$ & W & $10 y 5 m$ \\
\hline 74 & $\mathrm{~F}$ & W & $13 y 7 m$ \\
\hline
\end{tabular}

$\mathrm{NW}=$ Non-white. 
Appendix A (continuation): All patients gender, race and age.

\begin{tabular}{|c|c|c|c|}
\hline Patient & Gender & Race & Age \\
\hline 75 & $\mathrm{~F}$ & W & $13 \mathrm{y} 10 \mathrm{~m}$ \\
\hline 76 & $\mathrm{~F}$ & W & $10 y$ \\
\hline 77 & $\mathrm{~F}$ & W & $11 \mathrm{y} 5 \mathrm{~m}$ \\
\hline 78 & M & W & $14 \mathrm{y} 6 \mathrm{~m}$ \\
\hline 79 & $\mathrm{~F}$ & W & $10 y 7 m$ \\
\hline 80 & $\mathrm{~F}$ & W & $11 \mathrm{y} 11 \mathrm{~m}$ \\
\hline 81 & $\mathrm{~F}$ & W & $15 \mathrm{y} 1 \mathrm{~m}$ \\
\hline 82 & $M$ & W & $11 \mathrm{y} 7 \mathrm{~m}$ \\
\hline 83 & $\mathrm{~F}$ & W & $15 \mathrm{y} 6 \mathrm{~m}$ \\
\hline 84 & $\mathrm{~F}$ & W & $14 y 6 m$ \\
\hline 85 & $\mathrm{~F}$ & NW & $30 y 2 m$ \\
\hline 86 & M & W & $11 \mathrm{y} 4 \mathrm{~m}$ \\
\hline 87 & $\mathrm{~F}$ & W & $10 \mathrm{y} 11 \mathrm{~m}$ \\
\hline 88 & $\mathrm{~F}$ & W & $11 \mathrm{y} 2 \mathrm{~m}$ \\
\hline 89 & $\mathrm{~F}$ & W & 9y9m \\
\hline 90 & M & W & $10 y 9 m$ \\
\hline 91 & $\mathrm{~F}$ & W & $10 y 9 m$ \\
\hline 92 & $M$ & W & $9 y 11 m$ \\
\hline 93 & $M$ & $W$ & $13 y 2 m$ \\
\hline 94 & $\mathrm{~F}$ & W & $13 y 1 m$ \\
\hline 95 & M & W & $11 \mathrm{y} 6 \mathrm{~m}$ \\
\hline 96 & $\mathrm{~F}$ & W & $9 \mathrm{y} 1 \mathrm{~m}$ \\
\hline 97 & $M$ & W & $9 y 5 m$ \\
\hline 98 & M & W & $8 y 10 m$ \\
\hline 99 & $M$ & W & $9 y 7 m$ \\
\hline
\end{tabular}

\begin{tabular}{|c|c|c|c|}
\hline Patient & Gender & Race & Age \\
\hline 100 & $\mathrm{~F}$ & W & $7 y 6 m$ \\
\hline 101 & $\mathrm{~F}$ & W & $10 y 5 m$ \\
\hline 102 & $\mathrm{M}$ & W & $12 \mathrm{y} 5 \mathrm{~m}$ \\
\hline 103 & $\mathrm{~F}$ & W & $10 y 8 m$ \\
\hline 104 & $\mathrm{M}$ & W & $12 \mathrm{y} 6 \mathrm{~m}$ \\
\hline 105 & $M$ & NW & $11 \mathrm{y} 11 \mathrm{~m}$ \\
\hline 106 & $M$ & W & $12 \mathrm{y} 10 \mathrm{~m}$ \\
\hline 107 & $M$ & W & $7 y 11 m$ \\
\hline 108 & $\mathrm{~F}$ & W & $12 y 3 m$ \\
\hline 109 & $\mathrm{M}$ & W & $11 \mathrm{y} 1 \mathrm{~m}$ \\
\hline 110 & $M$ & W & $9 \mathrm{y} 10 \mathrm{~m}$ \\
\hline 111 & $\mathrm{~F}$ & W & $10 y 7 m$ \\
\hline 112 & $\mathrm{~F}$ & NW & $10 \mathrm{y} 10 \mathrm{~m}$ \\
\hline 113 & $\mathrm{M}$ & W & $10 y 4 m$ \\
\hline 114 & $\mathrm{~F}$ & W & $11 \mathrm{y} 4 \mathrm{~m}$ \\
\hline 115 & $M$ & W & $11 \mathrm{y} 4 \mathrm{~m}$ \\
\hline 116 & $M$ & W & $8 y 3 m$ \\
\hline 117 & $\mathrm{~F}$ & W & $8 y 8 m$ \\
\hline 118 & $\mathrm{~F}$ & W & $8 y 2 m$ \\
\hline 119 & M & W & $10 y 2 m$ \\
\hline 120 & $\mathrm{~F}$ & NW & $8 y 6 m$ \\
\hline 121 & $\mathrm{M}$ & W & $12 y$ \\
\hline 122 & $M$ & W & $14 y 7 m$ \\
\hline 123 & $\mathrm{~F}$ & W & $18 \mathrm{y} 1 \mathrm{~m}$ \\
\hline
\end{tabular}

$\mathrm{NW}=$ Non-white

\section{DISCUSSION}

The success of miniscrews is related to their primary stability that is defined by the absence of mobility in the bone after their insertion ${ }^{17}$ and this depends on the adaptation and mechanical retention of these devices in the bone tissue. ${ }^{18}$ The anatomy of the bony site, especially the cortical bone thickness, plays a fundamental role in this mechanical bracing, and consequently influences the success or failure of the device. 
The results of this study suggested that the cortical bone thickness varied according to the age of the individuals. Young patients tended to have thinner cortical bone, in comparison with older individuals. Brachycephalic patients tended to have thicker cortical bone in the mandible. The variables sex, skin color, and sagittal facial pattern did not significantly influence the cortical bone thickness of the mandible and maxilla.

The difference in cortical bone thickness found in patients of different age groups may explain the results obtained in previous studies that observed the rate of maxillary miniscrews loss in adolescents. Moon et al. ${ }^{19}$, in a clinical study that evaluated the influencing factors and success rate of 778 miniscrews in 306 patients, reported success in $76.1 \%$ of adolescents and $87.3 \%$ of adults. The increase in cortical bone thickness could be due to changes in the functional capacity of the individuals, since the masticatory force, muscle size and activity tend to increase with age. ${ }^{20-22}$

The results obtained corroborated the findings of previous studies that evaluated the cortical thickness at miniscrew insertion sites. Farnsworth et al. ${ }^{23}$ correlated the cortical thickness with the age and sex of patients. However, they found thicker cortical bone in adults (20-45 years) when compared with adolescents (11-16 years). 
Ohiomoba et al. ${ }^{24}$ showed that the increase in age was positively correlated with cortical bone thickness: 16 year-old or older patients had significantly thicker cortical bone, in comparison with patients between 12 and 16 years of age, but the bone thickness remained almost constant from the age of 16 years onwards. Similar results were reported by Fayed et al..$^{25}$ : individuals between 19 and 27 years of age showed thicker vestibular and palatal cortical bone when compared with the younger patients (13-18 years).

In the present study, brachycephalic patients showed thicker cortical bone, both in the maxilla and mandible, when compared with mesocephalic and dolichocephalic patients, however, this difference was statistically significant only in the mandibular cortical bone. Swasty et al. ${ }^{26}$ observed the same differences in vertical facial patterns.

The linear regression results showed that the vertical facial pattern influenced the mandibular cortical measurements. This tendency was observed in the vestibular cortical of the maxilla, however, without statistical significance. This result may have been due to the real absence of association or due to sample size. Horner et al. ${ }^{27}$ evaluated the cortical bone thickness in hyperdivergent and hypodivergent adults and concluded that in the majority of the studied sites, hypodivergent patients presented thicker cortical bone than hyperdivergent individuals. 
Although the data showed that the cortical thickness values of non-white patients were higher than those of white individuals in all the evaluated sites, this difference was not statistically significant; and in the multivariate regression the skin color showed no influence on the cortical thickness. However, further studies are needed with groups that have a balanced distribution, considering that the sample of the present study included 107 white individuals and only 16 non-white individuals.

In addition, it is suggested that other variables should be included in future studies such as: the individuals' diet and masticatory force, since they are factors that may be associated with the difference in bone thickness and density. Clinical studies are also encouraged to evaluate the success rate of miniscrews and the variables that may influence the bone characteristics of patients.

A limitation of the present study was the $0.4 \mathrm{~mm}$ voxel size used in the CBCT acquisition protocol. According to Ballrick et al. ${ }^{28}$, the mean spatial resolution for voxel used in orthodontics is $0.7 \mathrm{~mm}$. Thus, the accuracy of measurements smaller than $0.7 \mathrm{~mm}$ was not reliable, and should be observed with caution. However, considering that the advantage would be an increase in the precision and accuracy of the measurements obtained by means of CBCT, the disadvantage produced by the reduction in voxel size from $0.4 \mathrm{~mm}$ to $0.25 \mathrm{~mm}$ would be the 
increase in the dose of ionizing radiation to which the patients would be exposed. Moreover, the minority of thickness values obtained in this study were lower than $0.7 \mathrm{~mm}$.

The main contribution of this study was the evaluation of cortical bone thickness with reference to different variables related to the individuals, such as age, sex, skin color and vertical and sagittal facial patterns, by performing the multivariate analysis, which made it possible to verify the influence of each individual variable and its interaction on the outcome.

It is important to point out that although young patients $(<12$ years) are not the individuals commonly eligible for the placement of miniscrews, their inclusion in this study allowed the variation in the pattern of cortical bone thickness to be according to age.

\section{CONCLUSIONS}

The increase of cortical bone thickness was positively associated with age. Adjusted linear regression analysis showed that at each increase in age, the mean cortical thickness values increased by $0.06 \mathrm{~mm}$ in the mandible, $0.03 \mathrm{~mm}$ in the vestibular region and $0.02 \mathrm{~mm}$ in the palatal region of the maxilla. Brachycephalic patients presented higher cortical bone thickness values. The variables sex, sagittal facial pattern and skin color of the patients did not influence the cortical bone thickness in the interradicular areas of miniscrews insertion. 
AUTHORS' CONTRIBUTIONS

Anna Carolina T. Centeno (ACTC)

Caroline Kolling Fensterseifer (CKF)

Vitória de Oliveira Chami (VOC)

Eduardo Silveira Ferreira (ESF)

Mariana Marquezan (MM)

Vilmar Antônio Ferrazzo (VAF)
Conception or design of the study:

ACTC, MM, VAF.

Data acquisition, analysis or

interpretation:

ACTC, CKF, VOC, ESF, MM, VAF.

Writing the article:

ACTC, CKF, MM.

Critical revision of the article:

ACTC, CKF, VOC, ESF, MM, VAF.

Final approval of the article:

ACTC, CKF, VOC, ESF, MM, VAF.

\section{Fundraising:}

ACTC.

Overall responsibility:

ACTC, VAF.

Patients displayed in this article previously approved the use of their facial and intraoral photographs.

The authors report no commercial, proprietary or financial interest in the products or companies described in this article. 


\section{REFERENCES}

1. Papadopoulos MA, Tarawneh F. The use of miniscrew implants for temporary skeletal anchorage in orthodontics: a comprehensive review. Oral Surg Oral Med Oral Pathol Oral Radiol Endod. 2007 May;103(5):e6-15.

2. Reynders R, Ronchi L, Bipat S. Mini-implants in orthodontics: a systematic review of the literature. Am J Orthod Dentofacial Orthop. 2009 May;135(5):564.e1-19; discussion 564-5.

3. Motoyoshi M, Uemura M, Ono A, Okazaki K, Shigeeda T, Shimizu $\mathrm{N}$. Factors affecting the long-term stability of orthodontic miniimplants. Am J Orthod Dentofacial Orthop. 2010 May;137(5):588. e1-5; discussion 588-9.

4. Wilmes B, Rademacher C, Olthoff G, Drescher D. Parameters affecting primary stability of orthodontic mini-implants. J Orofac Orthop. 2006 May;67(3):162-74.

5. Cheng SJ, Tseng IY, Lee JJ, Kok SH. A prospective study of the risk factors associated with failure of mini-implants used for orthodontic anchorage. Int J Oral Maxillofac Implants. 2004 Jan-Feb;19(1):100-6.

6. Freudenthaler JW, Haas R, Bantleon HP. Bicortical titanium screws for critical orthodontic anchorage in the mandible: a preliminary report on clinical applications. Clin Oral Implants Res. 2001 Aug;12(4):358-63.

7. Trisi P, Rao W, Rebaudi A. A histometric comparison of smooth and rough titanium implants in human low-density jawbone. Int J Oral Maxillofac Implants. 1999 Sep-Oct;14(5):689-98. 
8. Migliorati M, Drago S, Schiavetti I, Olivero F, Barberis F, Lagazzo A, et al. Orthodontic miniscrews: an experimental campaign on primary stability and bone properties. Eur J Orthod. 2015 Oct;37(5):531-8.

9. Marquezan M, Mattos CT, Sant'Anna EF, de Souza MM, Maia LC. Does cortical thickness influence the primary stability of miniscrews?: a systematic review and meta-analysis. Angle Orthod. 2014 Nov;84(6):1093-103.

10. American Academy of Oral and Maxillofacial Radiology. Clinical recommendations regarding use of cone beam computed tomography in orthodontics. [corrected]. Position statement by the American Academy of Oral and Maxillofacial Radiology. Oral Surg Oral Med Oral Pathol Oral Radiol. 2013 Aug;116(2):238-57.

11. Steiner CC. Cephalometric in clinical practice. Angle Orthod. 1959;29(1):8-29.

12. Ricketts RM, Roth RH, Chaconas SJ, Schulhof RJ, Engel GA. Bioprogressive technique of Ricketts. Buenos Aires: Panamericana; 1983.

13. Deguchi T, Nasu M, Murakami K, Yabuuchi T, Kamioka H, TakanoYamamoto T. Quantitative evaluation of cortical bone thickness with computed tomographic scanning for orthodontic implants. Am J Orthod Dentofacial Orthop. 2006 Jun;129(6):721.e7-12.

14. Schnelle MA, Beck FM, Jaynes RM, Huja SS. A radiographic evaluation of the availability of bone for placement of miniscrews. Angle Orthod. 2004 Dec;74(6):832-7. 
15. Lim WH, Lee SK, Wikesjö UM, Chun YS. A descriptive tissue evaluation at maxillary interradicular sites: implications for orthodontic mini-implant placement. Clin Anat. 2007 Oct;20(7):7605.

16. Antoszewska J, Papadopoulos MA, Park HS, Ludwig B. Five-year experience with orthodontic miniscrew implants: a retrospective investigation of factors influencing success rates. Am J Orthod Dentofacial Orthop. 2009 Aug;136(2):158.e1-10; discussion 158-9.

17. Javed F, Romanos GE. The role of primary stability for successful immediate loading of dental implants. A literature review. J Dent. 2010 Aug;38(8):612-20.

18. Cehreli MC, Karasoy D, Akca K, Eckert SE. Meta-analysis of methods used to assess implant stability. Int J Oral Maxillofac Implants. 2009 Nov-Dec;24(6):1015-32.

19. Moon CH, Park HK, Nam JS, Im JS, Baek SH. Relationship between vertical skeletal pattern and success rate of orthodontic miniimplants. Am J Orthod Dentofacial Orthop. 2010 Jul;138(1):51-7.

20. Usui T, Uematsu S, Kanegae H, Morimoto T, Kurihara S. Change in maximum occlusal force in association with maxillofacial growth. Orthod Craniofac Res. 2007 Nov;10(4):226-34.

21. Raadsheer MC, Kiliaridis S, Van Eijden TM, Van Ginkel FC, PrahlAndersen B. Masseter muscle thickness in growing individuals and its relation to facial morphology. Arch Oral Biol. 1996 Apr;41(4):32332. 
22. Braun S, Hnat WP, Freudenthaler JW, Marcotte MR, Hönigle $K$, Johnson BE. A study of maximum bite force during growth and development. Angle Orthod. 1996;66(4):261-4.

23. Farnsworth D, Rossouw PE, Ceen RF, Buschang PH. Cortical bone thickness at common miniscrew implant placement sites. Am J Orthod Dentofacial Orthop. 2011 Apr;139(4):495-503.

24. Ohiomoba H, Sonis A, Yansane A, Friedland B. Quantitative evaluation of maxillary alveolar cortical bone thickness and density using computed tomography imaging. Am J Orthod Dentofacial Orthop. 2017 Jan;151(1):82-91.

25. Fayed MM, Pazera P, Katsaros C. Optimal sites for orthodontic miniimplant placement assessed by cone beam computed tomography. Angle Orthod. 2010 Sep;80(5):939-51.

26. Swasty D, Lee J, Huang JC, Maki K, Gansky SA, Hatcher D, et al. Crosssectional human mandibular morphology as assessed in vivo by cone-beam computed tomography in patients with different vertical facial dimensions. Am J Orthod Dentofacial Orthop. 2011 Apr;139(4 Suppl):e377-89.

27. Horner KA, Behrents RG, Kim KB, Buschang PH. Cortical bone and ridge thickness of hyperdivergent and hypodivergent adults. Am J Orthod Dentofacial Orthop. 2012 Aug;142(2):170-8.

28. Ballrick JW, Palomo JM, Ruch E, Amberman BD, Hans MG. Image distortion and spatial resolution of a commercially available conebeam computed tomography machine. Am J Orthod Dentofacial Orthop. 2008 Oct;134(4):573-82. 